\title{
PERFORMANCE ANALYSIS OFBIO-DIESEL PRODUCED FROM WASTE COOKING OIL ON CI ENGINE
}

\author{
Dinesh Nichat ${ }^{1}$, L.V Kamble ${ }^{2}$ \\ ${ }^{l}$ Department of Mechanical Engineering, D.Y.Patil School of Engineering Academy, Talegaon (Ambi), Savitribai \\ Phule Pune University, Maharashtra, India. \\ ${ }^{2}$ Department of Mechanical Engineering, D.Y.Patil School of Engineering Academy, Talegaon (Ambi), Savitribai \\ Phule Pune University, Maharashtra, India.
}

\begin{abstract}
Exploring renewable energy sources is the need of present fuel scenario; the petro-fuels are vanishing more rapidly to meet heavy demands of today's population. The Bio-fuels looks attractive and inviting source in this situation. Bio-diesel as a fuel of this category are more environmental benefits as a cleaner fuel compare to the petrol-diesel. Bio-diesel is the product of the process known as a 'stratification' in which Triglycerides from soybean oil reacts with alcohol under action of certain catalysts at specific constant temperature for specific time interval to produce bio-diesel as a result. Bio-diesel can be use in internal-combustion engine as a fuel application solely or blending with petrol-diesel. Lots of benefits of using biodiesel as a fuel it is renewable source, burns cleaner than petrol-diesel and compatible with petrol-diesel. Bio-diesel can be produced through many techniques including acid \& base catalysis, enzymatic conversion, solid catalysis, non-catalytic conversion and super-critical methanolysis. India being preponderantly agricultural country needs major attention for the fulfillment of energy demands of a farmer. Irrigation could be a bottleneck of Indian agriculture, it's to be developed on giant scale, however at a similar time diesel oil consumption should be unbroken to a minimum level due to the price of diesel and its inadequacy. The rise use of diesel in agriculture and transportation sectors has resulted in diesel crises. Oil and electricity are two major fuels that are employed in agriculture sector.
\end{abstract}

Keywords: Biodiesel, Acid Catalyst, Transesterification

\section{INTRODUCTION}

The present work is carried out using typical oil i.e. Waste cooking oil as a fuel. However major disadvantage of Waste cooking oil is its viscosity, which is order of magnitude higher that of petroleum based diesel. The fuel injection system of new technology engines is sensitive to fuel viscosity changes. High viscosity of vegetable oil leads to poor fuel atomization, which in turn may lead to poor combustion, ring sticking, injector cooking, injector deposits, injector pump failure and lubricating oil dilution. Viscosity of waste cooking oil must be reduced in order to improve its engine performance. In the present work viscosity of Waste cooking oil was reduced by transesterification process. Transesterification via Acid catalysis is done instead of Base Catalysis. Base Catalysis Proven Improper for FFA Level more than 5\% which results in extra consumption of base catalysis and soap formations. Furthermore the different Acid Catalysts e.g. Hydrochloric Acid, Nitric Acid and Sulfuric Acid used for biodiesel production and its productivity is measured. The optimum combination for Each Acid catalyst is established. So the three Bio-diesels are produced for each acid catalyst. Finally The Blends are prepared for Each Biodiesel in terms of B20, $\mathrm{B} 30$ and B40.
The different parameters considered for comparing the performance of blends with that of diesel fuel operation were brake specific fuel consumption, thermal efficiency, brake power, exhaust gas temperature at speed of $1500 \mathrm{rpm}$.

\subsection{Experimental Fuels}

The main fuels used are diesel as baseline fuel, Biodiesel Produced using Sulfuric Acid (BD-1), Biodiesel Produced using Hydrochloric Acid (BD-2) \& Biodiesel Produced using Nitric Acid (BD-3) The various Physico-Chemical and other properties of fuels is given in following table no 1.1

Table- 1.1: Properties of fuels

\begin{tabular}{|c|c|c|c|c|c|}
\hline $\begin{array}{c}\text { Sr } \\
\text { no }\end{array}$ & Properties & Diesel & BD1 & BD2 & BD3 \\
\hline 1 & $\begin{array}{c}\text { Density } \\
(\mathrm{Kg} / \mathrm{m} 3)\end{array}$ & 823 & 845 & 850 & 836 \\
\hline 2 & $\begin{array}{c}\text { Calorific } \\
\text { value } \\
(\mathrm{MJ} / \mathrm{kg})\end{array}$ & 43 & 40.90 & 40.30 & 38.52 \\
\hline 3 & $\begin{array}{c}\text { Viscosity } \\
\left(40^{\circ} \mathrm{C}(\mathrm{cst})\right.\end{array}$ & 3.9 & 5.2 & 5.78 & 4.99 \\
\hline 4 & $\begin{array}{c}\text { Flash point } \\
\left({ }^{\circ} \mathrm{C}\right)\end{array}$ & 72 & 120 & 130 & 135 \\
\hline 5 & Fire Point & 78 & 126 & 137 & 141 \\
\hline 6 & TAN & 0.1750 & 0.2125 & 0.3585 & 0.4510 \\
\hline
\end{tabular}




\subsection{Blend Preparation}

The different blends of diesel and Biodiesel were prepared on volume basis. The blends were prepared in blender. The various blends prepared are given as follows. The three Blends are prepared from each Acid Biodiesels. We have BD Via Sulfuric Acid (BD1), BD Via Hydrochloric Acid (BD2) \& BD Via Nitric Acid (BD3). Total Nine Blends are Prepared.

Blends of Diesel \& BD-1

1) B20 (80\% diesel $20 \%$ BD-1)

2) $\mathrm{B} 30(70 \%$ diesel $30 \% \mathrm{BD}-1)$

3) B40 (60\% diesel $40 \%$ BD-1)

Blends of Diesel \& BD-2

4) B 20 (80\% diesel $20 \%$ BD-2)

5) $\mathrm{B} 30(70 \%$ diesel $30 \% \mathrm{BD}-2)$

6) B40 (60\% diesel $40 \%$ BD-2)

Blends of Diesel \& BD-3

7) B 20 (80\% diesel $20 \%$ BD-3)

8) B $30(70 \%$ diesel $30 \%$ BD-3)

9) B40 (60\% diesel $40 \%$ BD-3)

Table- 1.2:Properties of various blends

\begin{tabular}{|c|c|c|c|c|c|}
\hline SN & $\begin{array}{c}\text { Blen } \\
\text { ds }\end{array}$ & $\begin{array}{c}\text { Density } \\
(\mathrm{Kg} / \mathrm{m} 3)\end{array}$ & $\begin{array}{c}\text { Calorific } \\
\text { value } \\
(\mathrm{MJ} / \mathrm{kg})\end{array}$ & $\begin{array}{c}\text { Viscosity@ 40 } \\
\mathrm{C}(\mathrm{cst})\end{array}$ & $\begin{array}{c}\text { Flash } \\
\text { point } \\
\left({ }^{\circ} \mathrm{C}\right)\end{array}$ \\
\hline \multicolumn{6}{|c|}{ Blends of BD Via Sulfuric Acid (BD1) } \\
\hline 1 & B20 & 825 & 42.600 & 4.16 & 81 \\
\hline 2 & B30 & 829 & 42.380 & 4.30 & 86 \\
\hline 3 & B40 & 833 & 42.150 & 4.45 & 92 \\
\hline \multicolumn{7}{|c|}{ Blends of BD Via Hydrochloric Acid (BD2) } \\
\hline 4 & B20 & 827 & 42.500 & 4.22 & 83 \\
\hline 5 & B30 & 832 & 42.300 & 4.35 & 88 \\
\hline 6 & B40 & 835 & 41.150 & 4.65 & 96 \\
\hline \multicolumn{7}{|c|}{ Blends of BD Via Nitric Acid (BD3) } \\
\hline 7 & B20 & 831 & 41.900 & 4.12 & 85 \\
\hline 8 & B30 & 835 & 41.656 & 4.23 & 91 \\
\hline 9 & B40 & 840 & 40.208 & 4.60 & 98 \\
\hline
\end{tabular}

\section{EXPERIMENTAL SETUP}

The test engine for experimental purpose is single cylinder, four-stroke, water cooled, constant speed, direct injection diesel engine. The engine is to be connected to the dynamometer which can give the maximum of $3.7 \mathrm{~kW}$ of power; the engine has dimension of $110 \times 80 \mathrm{~mm}$ of stroke to bore value.

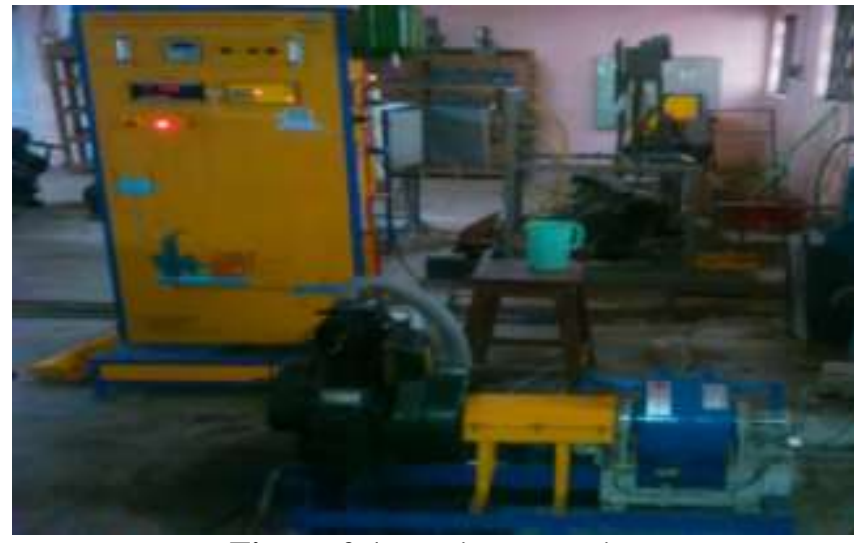

Figure-2.1: Engine Test Rig

\subsection{Data Acquisition System}

NIYO ENGINEER SOFTWARE Model: HMT07" is used to analyze the output data of the engine. This Software has different channel in which each channel has specific function. Fuel level channel indicates the fuel level with the help of fuel level sensor. The Load Indicator channel indicates the load after Switching on Load switch. This Software can also indicate pressure crank-angle diagram that indicates the pressure variation at every crank angle. Hence the combustion parameters such as Peak pressure and crank angle are obtained. It gives directly the Brake power, Brake Thermal Efficiency, Brake Specific Fuel Consumption at different load. It also indicates the Exhaust Gas Temperature in degree Celsius.

Testing conducted at various loads starting from No Load up to rated Load. The engine operated for 5 minutes at each load, to stabilize the engine under new conditions. The tests have conducted at the rated engine speed. The engine first run with diesel fuel, and the under steady state conditions, engine performance parameters such as brake power, brake specific fuel consumption, brake thermal efficiency \& exhaust gas temperature are recorded at various load, then engine is run with different biodiesel blends and the tests are performed.

\section{a) Brake Power}

The Niyo Software indicates the direct reading of brake power on output monitor at different load condition.

\section{b) Brake Thermal Efficiency}

The Niyo Software indicates the direct reading of brake thermal efficiency on output monitor.

\section{c) Exhaust Gas Temperature}

The Niyo Software indicates the direct reading on output monitor. It is the exhaust gas temperature indicated on monitor

\section{d) Fuel measuring system}

The Niyo Software indicates the direct Reading on channel of control panel Fuel measurement sensor is situated below the fuel tank which has function to measure Fuel 
Consumption by radiating laser beam on fuel. It supplies these data to DAS which indicates output on monitor.

\section{e) Dynamometer}

To calculate load on the engine the eddy current dynamometer mounted on the shaft of the engine. The load indicates Control Panel of DAS. The load is applied by the switching on load switch on control panel. Water is used cool brake drum. To calculate the brake power of the engine the load is to be given to the engine.

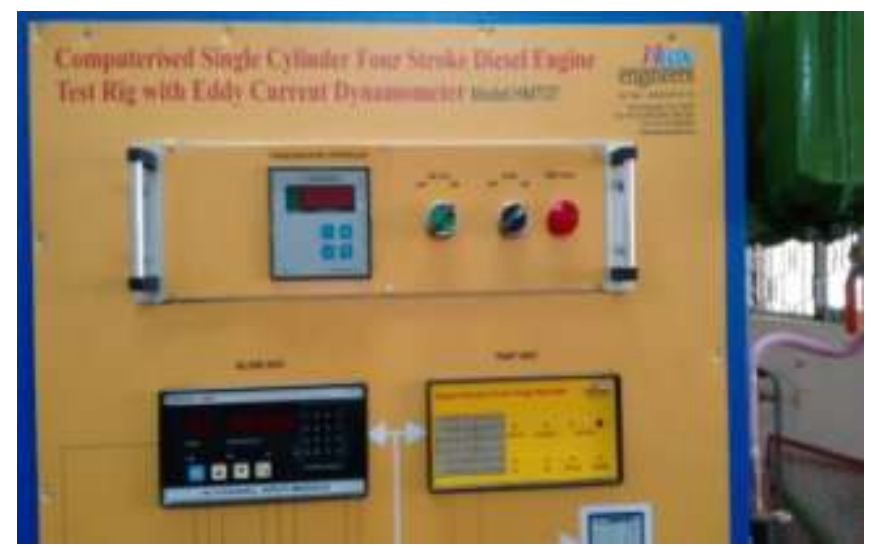

Fig-3.7.2: Control Panel to apply Load on Dynamometer

\subsection{Parameter selection}

The selections of appropriate parameters are essential for engine calculations, and parameters are selected very judiciously. The main parameters desired from the engine are listed below.

1. Power produced by engines

2. Brake Thermal Efficiency

3. Fuel consumption

4. Exhaust gas Temperature.

\subsection{Experimental Procedure}

The engine used for the study is single cylinder, four-stroke, air cooled, constant speed, direct injection diesel engine. Test will conduct using constant speed.

The engine is started by pushing the switch on control panel at no load by pressing fuel supply valve to attain rated speed still the steady state condition is reached.

After attaining constant engine speed, the load is applied by switching on the Load switch and increasing it gradually.

All readings of brake thermal efficiency, brake power, fuel consumption, and temperature of exhaust gas are taken from NIYO Software. The data for no load condition is includes brake power $(\mathrm{kW})$ brake thermal efficiency $(\%)$ and brake specific fuel consumption $(\mathrm{kg} / \mathrm{kW}-\mathrm{hr})$. The load is increased gradually from no load to peak load condition. The engine was loaded gradually keeping the speed within the permissible range and the observations of different parameters are taken after attaining steady state by running up to 5 minutes for each observation.
Short term performance tests are carried out on the engine diesel to generate base line data and subsequently Biodiesel different blends are used to evaluate its suitability as fuel. The load is varied within the interval of $0 \mathrm{~kW}$ to $4 \mathrm{~kW}$. Eddy current dynamometer is used to load the engine. All the observed data for each load conditions are noted. The same procedure is applied for different blends.

\subsection{Performance Curves For Various Blends}

\subsubsection{Performance Analysis of B20, B30 and B40}

\section{1) Brake Thermal Efficiency}
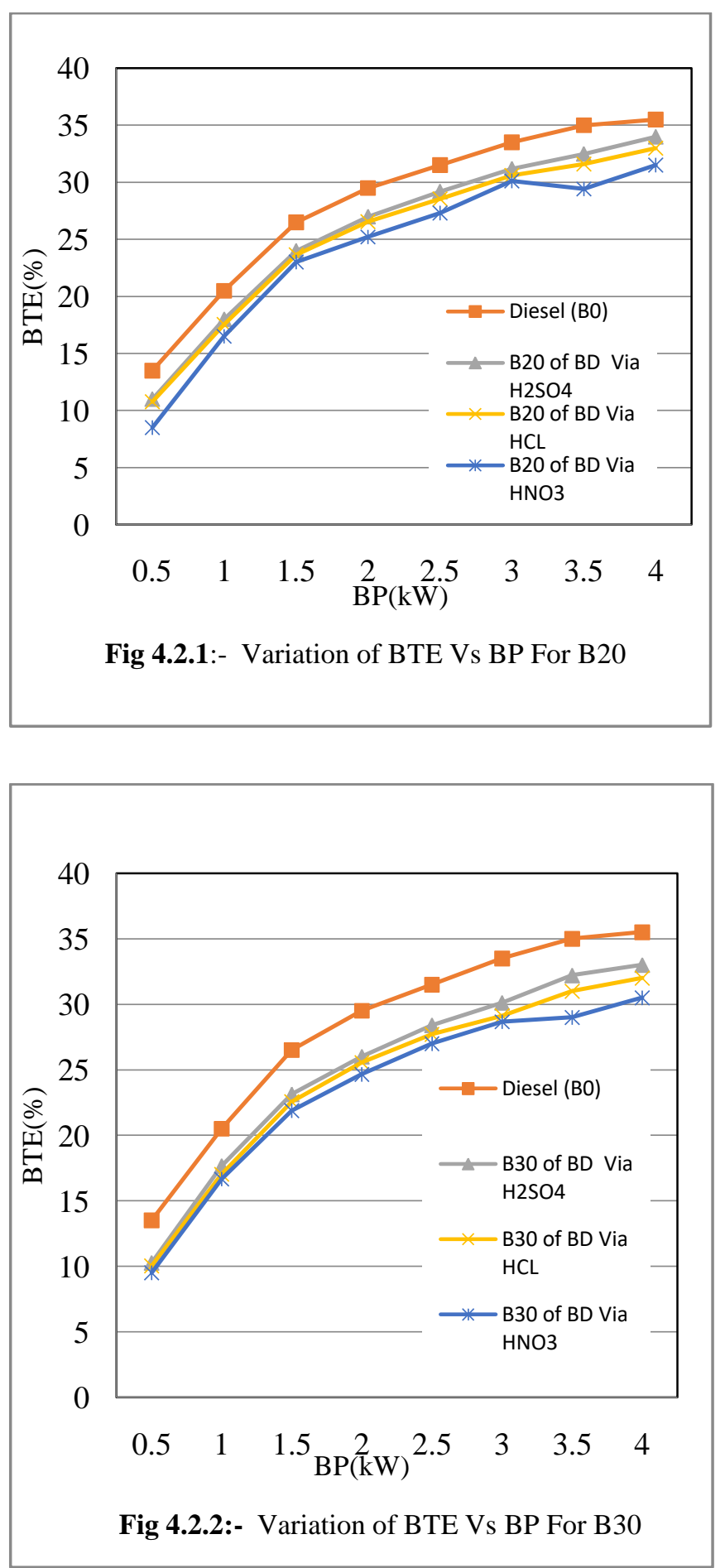


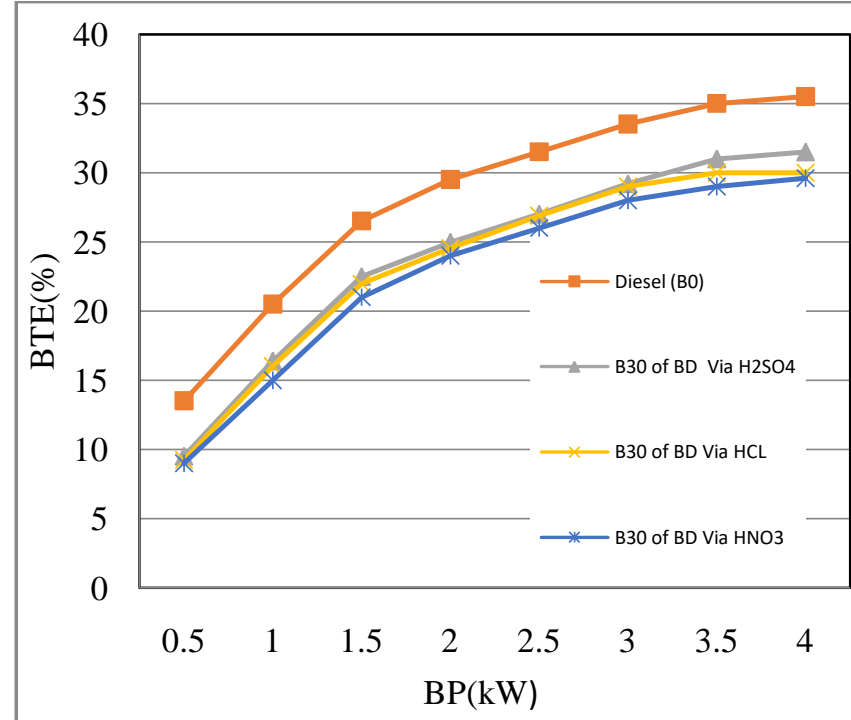

Fig4.2.3 :- Variation of BTE Vs BP For B40

Theincreased in Brake power (BP) with reduction in Total Fuel Consumption (TFC) helps to increase the Brake Thermal Efficiency (BTE). The Brake Thermal Efficiency is almost equal for all the Biodiesel blends due to increase in ignition delay. At higher load condition BTE slightly increases due to longer ignition delay leads to rapid increase in premixed heat release rate that affect BTE favorably. The BTE is higher for Diesel and decreases significantly with increase in blending proportion. The Figure (4.2.1), Figure (4.2.2) \& Figure (4.2.3) shows that the performance of BD1 \& BD2 is Similar but the result of BD1 is mo4re pronounced and better than BD3. At lower and part load the BTE is Similar but at high load the BD1 takes peak than BD2

\subsection{2) Brake Specific Fuel Consumption}

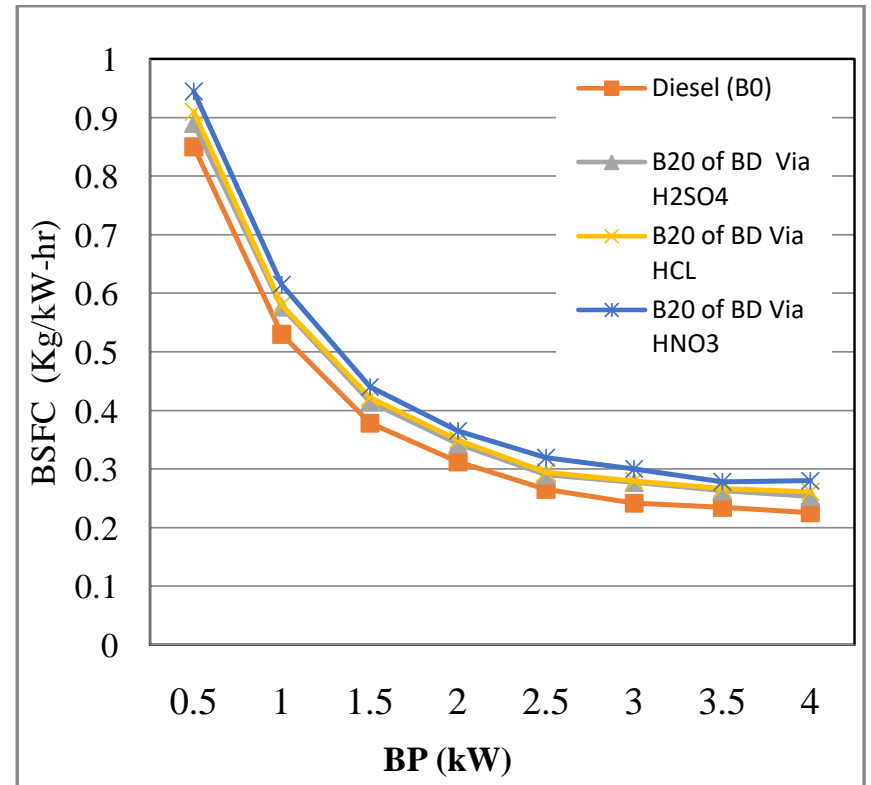

Fig 4.2.4:- Variation of BSFC Vs BP For B20

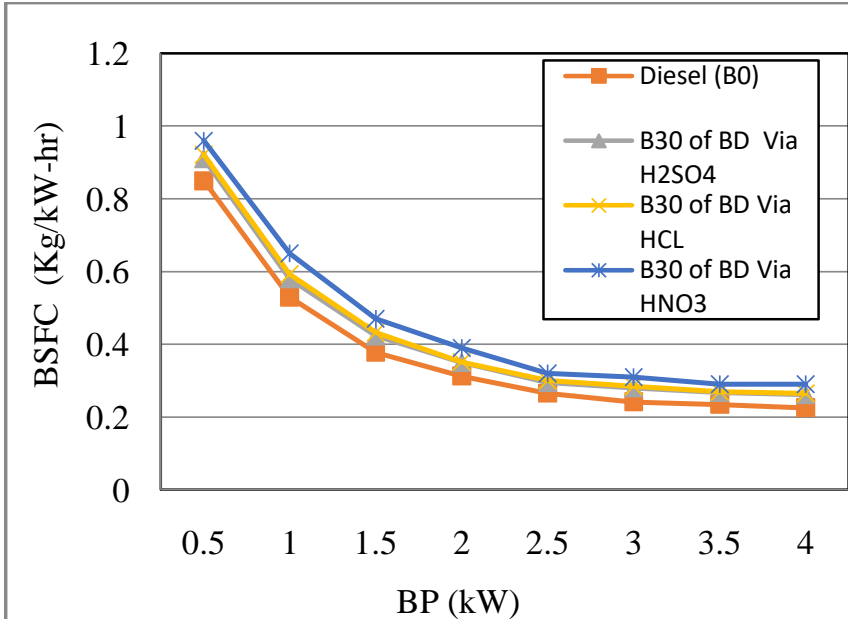

Fig 4.2.5 :- Variation of BSFCVs BP For 30

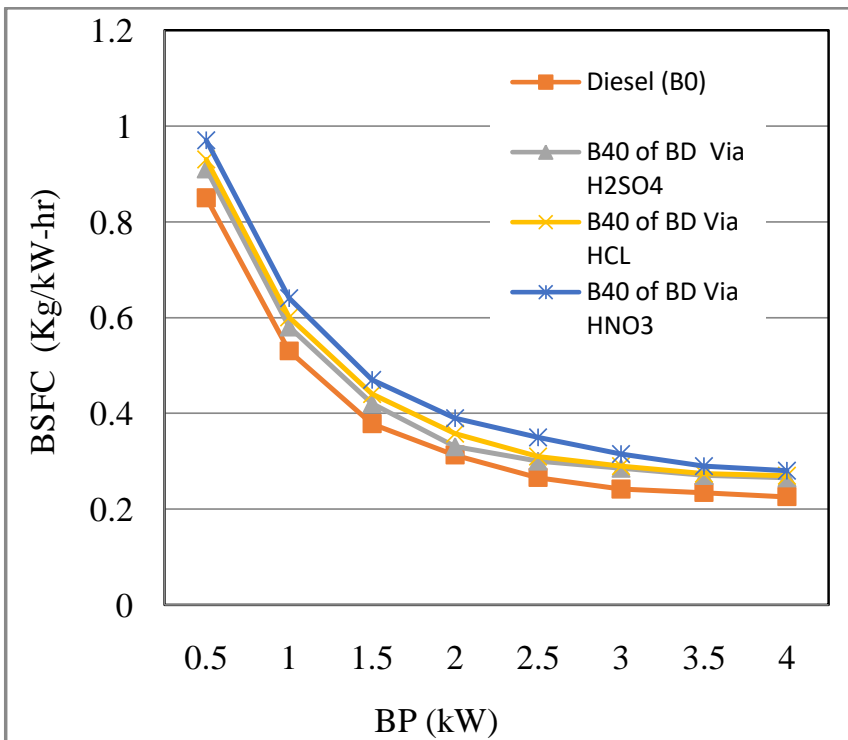

Fig 4.2.6:- Variation of BSFC Vs BP For 40

From Fig (4.2.4), Fig (4.2.5) \& Fig (4.2.6) it is seen that the BSFC decreases with increase in load. BSFC of diesel was lower than other blends. For BD1 and BD2 the performance in terms of BSFC is similar but at higher loads the BSFC BD1 Takes lower value which is reason for better BTE. The Performance of BD3 is lowest in three

\section{CONCLUSION}

The engine performance of engine decreases with increase in concentration of biodiesel. The optimum combination via Hydrochloric acid for Methanol/pretreated oil, acid concentration \& time wise is $0.16,1 \%$ \& 28 min which gives yield up to $81 \%$ which meets ASTM fuel requirements. The optimum combination Via Nitric Acid for Methanol /Pretreated oil, Acid concentration and Time wise is 0.20 , $1.25 \%$ and 50 min. whichgives yield up to $92.734 \%$ which meets ASTM Fuel requirements. The optimum combination Via Sulfuric Acid for Methanol / Pretreated oil, Acid concentration and Time wise is $0.20,1.5 \%$ and $24 \mathrm{~min}$. which gives yield up to $99.009 \%$ which meets ASTM Fuel 
requirements. The brake Thermal Efficiency of Blends BD1 and BD-2 is higher than BD-3. At lower load and Part load the performance of blend BD-1 and BD-2 is similar but at max load BTE performance of BD-1 is more pronounced.

\section{REFERENCES}

[1]. Sastry GSR, Krishna Murthy ASR, Ravi Prasad P, Bhuvaneswari K, Ravi PV.(2006) Identification and determination of bio-diesel in Diesel Energy Sources Part A;28:1337-42.

[2]. Knothe G, Dunn RO, Bagby MO (1997). Biodiesel: the use of vegetable oils and their derivatives as alternative Diesel fuels. Am ChemSocSymp Series; 666:172-208.

[3]. Hama S, Yamani H, Kaieda M, Oda M, Kondo A, Fukuda H (2004). Effect of fatty acid membrane composition on whole-cell biocatalysts for biodiesel-fuel production.BiochemEng J; 21:155-60.

[4]. Oda M, Kaieda M, Hama S, Yamaji H, Kondo A, Izumoto E, et al.(2004) Facilitatory effect of immobilized lipase-producing Rhizopusoryzae cells on acyl migration in biodiesel-fuel production. BiochemEng J; 23:45-51.

[5]. Shieh C-J,Liao H-F, LeeC-C.(2003) Optimization of lipase-catalyzed biodiesel by response surface methodology.Biores Technol;88:103-6.

[6]. Noureddini H, Gao X, Philkana RS. (2005) Immobilized pseudomonas cepacia lipase for biodiesel fuel production from soybean oil. BioresTechnol; 96:769-77

[7]. Demirbas A (2003). Biodiesel fuels from vegetable oils via catalytic and noncatalytic supercritical alcohol transesterifications and other methods: a survey. Energy Convers Manage; 44:2093-109.

[8]. Noureddini H, Gao X, Philkana RS. (2005) Immobilized pseudomonas cepacia lipase for biodiesel fuel production from soybean oil. BioresTechnol; 96:769-77.

[9]. Barnwal BK, Sharma MP. (2005) Prospects of Biodiesel production from vegetable oils in India. Renew Sust Energy Rev;9(4):363-78.

[10]. Srivastava A, Prasad R. (2000) Triglycerides-based diesel fuels. Renew Sust Energy Rev; 4:111-33.

Ma F, Hanna MA. (1999) Biodiesel production: a review. Bio resource Technology; 70:1-15

[11]. Fukuda H, Kondo A, Noda H (2001). Biodiesel fuel production by transesterification of oils. J BiosciBioeng ; 92(5):405-16

[12]. Barnwal BK, Sharma MP. (2005) Prospects of Biodiesel production from vegetable oils in India. Renew SustEnergy Rev; 9(4):363-78.

[13]. Y, Dube' MA, McLean DD, Kates M. (2003) Biodiesel production from waste cooking oil: 1. Process design and technological assessment. BioresourceTechnol; 89:1-16.

[14]. Freedman B, Pryde EH, Mounts TL (1984). Variables affecting the yields of fatty esters from transesterifiedvegetable oils. JAOCS;61(10):1638-43.

Noureddini H, Zhu D (1997). Kinetics of transesterification of soybean oil. JAOCS;74(11):1457-63.

[15]. Jagannath BalasahebHirkude, Atul S. Padalkar, "Performance and emission analysis of a compression ignition Engine operated on waste fried oil methyl esters", Applied Energy, (2012), Vol. 90, 68-72
[16]. S. Li, Y. Wang, S. Dong et al., "Biodiesel production from Eruca Sativa Gars vegetable oil and motor, emissions properties," Renewable Energy, vol. 34, no. 7, pp. 18711876, 2009.

[17]. N. A. Adeyemi, A. Mohiuddin, and T. Jameel, "Waste cooking oil transesterification: influence of impeller type, temperature, speed and bottom clearance on FAME yield," African Journal of Biotechnology, vol. 10, no. 44, pp. 89148929, 2011.

[18]. D. Darnoko and M. Cheryan, "Kinetics of palm oil transesterification in a batch reactor," Journal of the American Oil Chemists' Society, vol. 77, no. 12, pp. 12631267, 2000.

[19]. K. Kapilakarn and A. Peugtong, "A comparison of costs of biodiesel production from transesterication," International Energy Journal, vol. 8, no. 1, pp. 1-6, 2007.

[20]. IsmetÇelikten, EmreMutlu, HamitSolmaz, "Variation of performance and emission characteristics of a diesel engine fueled with diesel, rapeseed oil and hazelnut oil methyl ester blends"Renewable Energy, (2012), Vol. 48, 122-126

[21]. S.K.Acharya, M.K.MohantyR.K.Swain, "Kusum Oil as a Fuel for Small Horse Power Diesel Engine", International Journal of Engineering and Technology Vol. 1, No.3, (2009), ISSN: 1793-8236

[22].S K Acharya, A K Mishra, M Rath, C Nayak "Performance analysis of karanja and kusum oils as alternative bio-diesel fuel in diesel engine", Int. J. Agri.c \& Biol. Engg., (2011); Vol. no. 4(2). 